\title{
Social entrepreneurship as a way of developing sustainable township economies
}

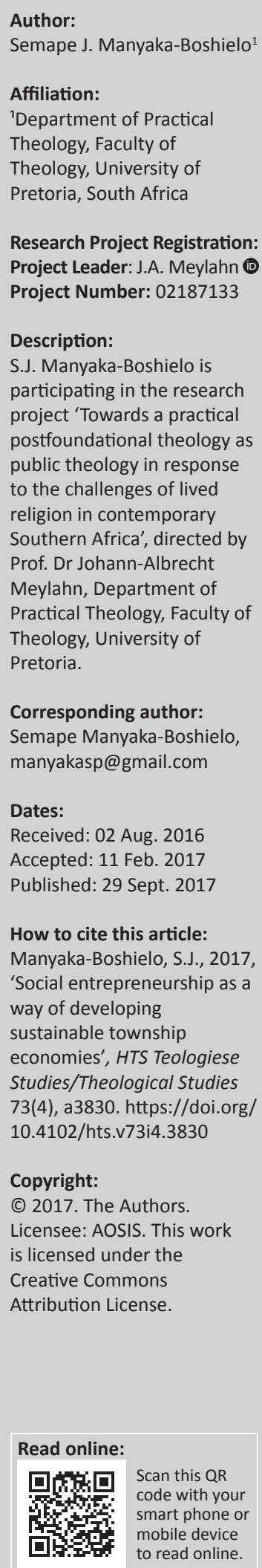

This article investigates using social entrepreneurship as a way of developing sustainable township economies, so that poverty can be eradicated from the townships of South Africa and township dwellers can begin to play a role in the economic development of the country. The author also thinks it is God's purpose for people to enjoy life, free from economic hardship. A reduction in poverty would also bring down the crime rate and other social ills. It starts by defining and clarifying the concepts of 'entrepreneur' and 'social entrepreneurship'. It continues by looking in more depth into township life and its challenges. This is done through reviewing the literature and observations obtained through participant observation research. Post-foundationalist practical theology believes in interdisciplinary dialogue as a means of allowing the concept of social entrepreneurship to bring about a sustainable township economy. From the author's observations, it became apparent that to see the attainment of a sustainable township economy, training and development should start with a strong emphasis on personal identity and interpersonal and business skills. The author, therefore, proposes a holistic approach to social entrepreneurship.

\section{Introduction}

South Africa has been described as a country where poverty is very high and this is unacceptable; youth unemployment, in particular, is very high (Taborda 2016). In 2015, 3.6 million young people (between $35 \%$ and $37 \%$ of this demographic) were unemployed and were actively looking for a job (Herrington \& Kew 2016:34). Entrepreneurship can help alleviate this situation. As early as 1995, Trevor Manuel, former Minister of Trade and Industry, identified unemployment as one of the major problems facing the new regime. He addressed the important mitigating role of entrepreneurship when he said 'small, medium and micro enterprise is an important vehicle to address the challenges of job creation, economic growth and equity in our country' (Herrington, Kew \& Kew 2009:12).

In its quarterly Labour Force Survey for January to March 2016, Statistics South Africa announced that 5.2 million people, or $26.7 \%$ of the population, were unemployed (Stats SA 2016). Total entrepreneurial activities (TEA) are low and an upward trend has not been maintained. According to Herrington and Kew (2016:5), in 2015, the TEA rate had regained some ground, from 7\% in 2014 to $9.2 \%$ in 2015. TEAs were also looked at from different populations in South Africa. In 2013 and 2014, approximately $85 \%$ of South African early-stage entrepreneurs were black Africans, but in 2015, this figure had declined by a fifth, to 68\% (Herrington \& Kew 2016:5). Clearly, other population groups were increasing their participation in TEA, particularly the Indian population. These authors also noted that most of those who were succeeding in entrepreneurial activities had a post-matric qualification.

\section{Methodology}

The research project is based on ethnographical research methodology. What is ethnographical research? It is a methodology which dictates that researchers learn about the lives of people they are interested in through first-hand experience in their daily lives (O'Reilly 2009:2). Angrosino (2007:14), put it this way, ethnography is the art and science of describing a human group - its institutions, interpersonal behaviours, material productions and beliefs.

Furthermore, ethnography means studying people in organised, enduring groups, which may be referred to as communities or societies (Angrosino 2007:1). The main method to be used by this methodology is participant observation. What is participant observation: it involves taking part as a member of a community while making mental and written, theoretically informed observation (O'Reilly 2009:2). The purpose of participation was two-fold: to understand things from a native's 
point of view and to blend into the setting so as to disturb it as little as possible (O'Reilly 2009:2).

This method works well with the researcher because the researcher works in the same organisation in which he is researching. Skrutkowski (2014) described that a covert ethnographic research is an approach that requires intense researcher involvement in the day-to-day running of an organisation so that a researcher can understand it from a researcher's point.

Angrosino (2007:37-49) stated that there are three data collection techniques: observation, interviewing and archival. How will this occur? The researcher will observe through five senses and take notes of everything. He or she will interview the people involved in what has been observed for more understanding of the context. Lastly, the researcher must check the written records of the particular context so that he or she can amplify the collected data.

\section{Historical development of the concept of entrepreneur}

The word 'entrepreneur' has a different meaning to different people. The term 'entrepreneur' originates from the 13thcentury French verb entreprendere meaning 'to do something or undertake' (Sobel 2008).

In 1700, Cantillon's entrepreneur is someone who acts in exchange for profit, especially someone who exercises business judgement in the face of uncertainty. This uncertainty, as Cantillon described it, occurs when entrepreneurs buy at a certain price to sell again at an uncertain price, with a positive difference being their profit (Herbert \& Link 2009:17).

Jean-Baptiste Say (1767-1832) broadened the concept by putting the entrepreneur at the core of the process (Herbert \& Link 2009:28). Herbert and Link (2009:29) summarised Say's theory of the entrepreneur by way of five main observations listed below:

1. The vigour of entrepreneurial activity depends upon the composition, distribution and security of property rights.

2. The theory is part of a division of human industry into three distinct operations: being scientific, the application of knowledge to a useful purpose and the manufacture of an item by manual labour.

3. The entrepreneur is the principal agent of production, whose role is vital to the production of utility.

4. The entrepreneur is an economic catalyst, a pivotal figure in economic development.

5. The entrepreneur is a superintendent and administrator.

Adam Smith, coming from the English economists' school of thought, saw an entrepreneur as a prudent man who is frugal (i.e. one who accumulates capital) and an agent of slow but steady progress (Herbert \& Link 2009:39). The element of the prudent man characterised Smith's entrepreneur as essentially passive: 'A prudent, cautious, not overly imaginative fellow, who adjusts to circumstances rather than brings about their modification'. Pesciarelli (1989:527-528) painted a picture of Smith's entrepreneur as an 'undertaker' who:

1. faces risk and uncertainty

2. formulates plans and projects in an effort to earn profit

3. seeks out the necessary capital for implementation of his planned undertaking

4. combines and organises the productive factors

5. inspects and directs production.

The German historical school produced Gustav Schmoller (1838-1917), who saw the entrepreneur as a creative organiser and manager, whose role was innovation and the initiation of new projects (Herbert \& Link 2009:95). What emerged from this German school was the breaking away from the old methods of production and creation of new ones.

Schumpeter, from the German historical school of economics, described the entrepreneur as the consummate innovator who earned his profits, however temporary, from successful innovations. Building on other schools of thought, he saw the entrepreneur as being at the centre of economic development (Herbert \& Link 2009). He introduced the concept of the process of 'creative destruction'. He argued that what has been produced previously must always be challenged and the way of doing things must change.

\section{Schumpeter (1934) argued that:}

everyone is an entrepreneur only when he actually carries out new combinations, and loses that character as soon as he has built up his business, when he settles down to running it, as other people run their businesses. (pp. 66-78)

The 'new combination' could involve the following: (1) creation of a new product, (2) a new method of production, (3) opening of the new market, (4) capture of a new source of supply or (5) a new organisation of industry. 'These new combinations we call enterprise ...; the individuals whose function is to carry them out we call entrepreneurs', and the entire process precipitates economic development.

Cole was influenced by Gay, a follower of Schumpeter; Cole (1949) defined entrepreneurship as:

\footnotetext{
the purposeful activity (including an integrated sequence of decisions) of an individual, or group of associated individuals, undertaken to initiate, maintain, or aggrandize a profit-oriented business unit for the production or distribution of economic goods and services with pecuniary or other advantage the goal or measure of success, in interaction with (or within the conditions established by) the internal situations of the unit itself or with the economic, political, and social circumstances (institutions and practices) of a period which allows an appreciable measure of freedom of decision. (p. 88)
}

The well-known author Drucker (1964) proposed that an entrepreneur searches for change, responds to it and exploits opportunities. Innovation is a specific tool of an entrepreneur; hence, an effective entrepreneur converts a source into resource. 
According to the Oxford Advanced Learner Dictionary, 'entrepreneur' means 'A person who makes money by starting or running businesses, especially when it involves taking financial risks'.

According to the above scholars, entrepreneurs are individuals with the ability to identify an opportunity, and, through innovative thinking and despite lack of resources, take action regarding the opportunity, to add value to prevailing economic conditions and into society. With this in mind, let us now look at the concept of social entrepreneurship.

\section{Concept of social entrepreneurship}

'Social entrepreneur' consists of two concepts: being socially minded and an entrepreneur. The question is how to relate these two concepts. The author's personal understanding is that the focus of 'social' is on addressing social concerns, while the 'entrepreneur' component is more geared towards generating profits or creating wealth. This understanding is based on the following definitions from the literature review.

Dees (1998:4) defined the entrepreneurial aspect of social entrepreneurship as including (1) the recognition and relentless pursuit of new opportunities to further the mission of creating social value, (2) continuous engagement in innovation and modification and (3) bold action undertaken without acceptance of existing resource limitations.

Austin, Stevenson and Wei-Skillern (2006:2) highlighted that social entrepreneurship is an innovative 'social valuecreating activity that can occur within or across the nonprofit, business, or government sectors'. The mission of social entrepreneurship is bringing betterment to those who have been marginalised so that they can transform their conditions.

Martin and Osberg (2007:35) point out that social entrepreneurship is not only about being paid for an innovation but about giving value to the under-served, neglected and marginalised sections of society. They define social entrepreneurship across three phases:

1. identifying a stable but inherently unjust equilibrium that causes the exclusion, marginalisation or suffering of a segment of humanity that lacks the financial means or political clout to achieve any transformative benefits on its own;

2. identifying an opportunity in this unjust equilibrium, developing a social value proposition and bringing to bear inspiration, creativity, direct action, courage and fortitude, thereby challenging the stable state's harmony;

3. forging a new, stable equilibrium that releases trapped potential or alleviates the suffering of the targeted group, and through imitation and the creation of a stable ecosystem around the new equilibrium, ensuring a better future for the targeted group or even society at large.

According to this view (Manyaka 2015:4), the social entrepreneur sees a problem in the community (an 'unjust equilibrium'), becomes alert to the opportunities that arise from the problem and devises and implements systems and procedures for solving, or, at least, addressing the problem. This intervention - an innovation in that situation - will bring about a new, more just and stable equilibrium that will bring some measure of relief to those who are trapped.

However, as an academic and researcher who lives in Nellmapius, the researcher has seen many organisations closed because of a lack of funding or donations. In an ideal world, through entrepreneurial business activities or mind set, they would be able to generate profit so that they could fund their social mission of adding value, which in turn would enable social entrepreneurs to contribute to developing a sustainable township economy, thereby destroying the unjust equilibrium set up during the colonial and apartheid periods and replacing it with a new equilibrium with the ability to release the potential among the poorest of the poor in excluded communities. But reaching this point requires sustained, exhaustive and collaborative effort by many stakeholders, and strategic and targeted interventions, as discussed below.

\section{Developing a sustainable township economy Township}

In South Africa, the term 'township' usually refers to the underdeveloped urban living areas that started the late 19th century and were reserved for 'non-whites' (Africans, 'mixed race' and Indians); many such townships still persist. During the apartheid period, non-whites were removed from suburbs that were designated as 'Whites Only'. These removals were made possible by the enactment of the Group Areas Act of 1950 (Manyaka 2010:80; Pieterse 2001:46-48), which created residential apartheid in South Africa.

Townships typically lack good infrastructure, and frequently informal settlements are found in township areas. The lack of infrastructure and amenities means that the vast majority of people living in townships must travel outside their residential areas to look for jobs. As the townships largely had the function of 'dormitory' areas for the working poor, the apartheid government did not build amenities or places of entertainment for the development of children in townships. According to the author's observations, the youth had no positive outlets for their energies, resulting in their becoming depressed and behaving in socially unproductive ways, such as involvement in criminal activity, high rates of teenage pregnancies in township areas, high school dropout rates and high levels of substance abuse.

In 1994, the first fully democratically elected government was formed. The new government is, and has been, trying to improve township spaces by building amenities and other infrastructure. However, it appears that there is still a limited sense of ownership of these amenities in the minds of the majority of township residents, who do not consider the amenities 'theirs', but think of them as belonging to the 
government. The researcher has observed that many of these improvements are not taken care of in the same way as those in middle- or upper-income suburbs, which previously werereserved exclusively for white people. For example, comparing a park in a suburban area with one in a township, the researcher noticed that the one in the suburb is better taken care of than the one in the township. It is still often the case that when community members are not happy with the government, they will burn and destroy public property as a sign of protest, thinking it belongs to the government, not to them. Sadly, even after over 20 years of democracy, township dwellers need a mindset change regarding their rights to and responsibilities towards public property.

\section{Economy}

'Economy' refers to the production, distribution and consumption of goods and services (Collier's Encyclopaedia 1963; The New Century Dictionary 1956). By extrapolation, 'township economy' would refer to the production, distribution and consumption of goods and services taking place in township areas.

As discussed above, townships in South Africa were created during the colonial and apartheid periods to ensure and perpetuate white people's privilege and power. One essential element of this was keeping blacks (used here as a collective term for Africans, mixed races, Indians and Asians) largely in the position of labourers in the economy. Other than labour, very little of economic value was produced in the townships, and goods and services distributed and consumed were largely imported from and owned by white people, resulting in low levels of economic benefit to township dwellers.

According to the 2015 State of the Province address by the Gauteng premier (Makhura 2015:19), township residents must be able to create the products and services they use. For example, he mentioned that stokvels and burial societies should be transformed into banks from which township businesspeople could borrow, because conventional banks have many requirements that township residents do not meet.

In his Capital City address, the City of Tshwane executive mayor emphasised that the City would assist and do business with small businesses from the marginalised communities. In addition, the City has initiated the Tshepo 10000 programme, aimed at empowering young people to become successful entrepreneurs (Ramokgopa 2015:6).

Recently, Absa Bank, as a strategic partner with the City, has trained 9344 beneficiaries in team building, group dynamics and financial management, and the University of Pretoria has offered entrepreneurial training to 10600 beneficiaries (Ramokgopa 2015:7). These efforts, if successful, could help transform the townships into centres of production of goods and services, and township dwellers into producers, not merely consumers, of these products.
At present, though the researcher has have observed that to get anything of good quality - better healthcare, better education, better services, etc. - people must go out of the township. On the flip side, the researcher has never observed whites, mixed race and Indians sending their children to attend school in the township, or for healthcare or grooming or church services, etc. One unfortunate consequence of this is that it has killed township dwellers' respect for one another, and anything African is considered to be suspect. Loosely translated, the African saying sehlare sa Mosotho ke lekgowa means the answer for a black person is a white person. The implication is that black people will depend upon white people for theirsurvival forever. This lack of self-belief and confidence must change if township economies are to be transformed.

The Gauteng provincial government is putting a great deal of resources and emphasis into township transformation: Makhura (2015:20) noted that in the 2015 financial year 'we have allocated more than R300 million to support township enterprises and cooperatives'. The plans of the Gauteng government and others have the potential to transform the face of the township life. Nevertheless, the author believes African township dwellers themselves must rise and become active participants in local economic and social development activities. The ball is in their court.

As social entrepreneurship emphasises the themes of opportunities, value creation, innovation and engineering a new equilibrium, it must be considered as a means of developing the township economy to its full.

\section{Innovation}

According to Schumpeter (1934), innovation means to look at things in a new way. There will be no transformation without an innovation mindset. For the township economy to be developed and sustained, the people in the township need to think in new ways and cannot stick to the patterns of the past. The community of Nellmapius needs more social and business entrepreneurs in order to experience social transformation in the township.

\section{Value creation}

Say introduced the concept of value creation and posited that entrepreneurs exist to create value in the economy, by moving the economy from low productivity to high productivity (Herrington et al. 2009:11). Social entrepreneurs such as Dees (1998) concur, arguing that value creation is one of the focus points of social entrepreneurship. This movement from low to high productivity will lead to community transformation.

Developing the township economy will require the value creators to truly sustain it. Reducing dependence on government and working towards self-reliance will also help grow the township economy and its sustainability. 


\section{Opportunities}

According to Dees (1998), social and business entrepreneurs recognise and relentlessly pursue opportunities for the creation of (social) value.

This recognition and development of opportunities play important roles in leading to the creation of a new venture: 'Identifying and selecting the right opportunities for new businesses are among the most important abilities of a successful entrepreneur' (Ardichvili, Cardozo \& Ray 2003:106). Furthermore, as Mitton (1989) writes:

Entrepreneurs see ways to put resources and information together in new combinations. They not only see the system as it is, but as it might be. They have a knack for looking at the usual and seeing the unusual, at the ordinary and seeing the extraordinary. Consequently they spot opportunities that turn the commonplace into the unique and unexpected. (p. 12)

\section{Unjust equilibrium}

This equilibrium causes people to accept that 'this is how things should be' or to accept it as the normal way of things. It is a static kind of life. However, entrepreneurs do not accept stasis as normal; instead, their new thinking challenges the unjust equilibrium so that a new equilibrium is created and causes economic development.

\section{Context of research: Township of Nellmapius}

Nellmapius is a township situated in Pretoria East and south of Mamelodi. The name Mamelodi means 'mother of melodies'. It is one of the big townships situated in the northeast of Pretoria, with a population of about 2.2 million people. Nellmapius is considered to be one of the poorest-of-the-poor townships in the area. According to Census 2011AdrianFrith. com, the Nellmapius population is about 56108 people. More than half of the population is unemployed. Some people work in temporary and very low paying jobs. In terms of its racial profile, Nellmapius is predominantly African, with only about 1019 mixed race in the area.

A small proportion of the people in Nellmapius live in 'bond' houses, that is, those for which they have taken out a mortgage, while the majority live in so-called reconstruction and development houses, which are the one-roomed houses they received from the government post-1994. In 2014, shacks were built along railway lines close to Mamelodi.

Nellmapius has only one clinic, which services the whole area. There are four primary schools and one high school. There are many unregistered early childhood development (ECD) centres across the township.

In every street of Nellmapius, there are more than two churches. This shows that the people of Nellmapius are believers. If the church could rise to her potential in terms of spiritual and other human development, it could become a primary agent of social transformation. The church must step up to the programmes that will change or transform the community.
From the author's personal observation, it appears that almost all spaza shops in Nellmapius are owned by foreign nationals, who are also visible as street vendors and car mechanics. From the perspective of this article, this is a concern: Where are the South African entrepreneurs? What factors inhibit South Africans from running businesses and engaging in entrepreneurship?

The researcher as a local pastor, chairperson of the Nellmapius pastors' forum and managing director of Phenyo Christian College (ECD), has been doing participant observational research in the township of Nellmapius from a unique vantage point since November 2010 to November 2011. Also, as a participating member of various transformational activities in the township, the author is involved in the process of addressing community problems in Nellmapius. These factors have contributed to the author's ability to conduct participant observation research in the township. The author's ultimate aim is to help alleviate poverty in this township through promoting social entrepreneurship activities as a means of localised wealth and job creation.

The researcher has attended the meetings of the following organisations; Nellmapius pastors' forum, ECD forum and small-business enterprises forum. The researcher collected data through notes taking as the general meetings progress. From these general meetings, the research usually requested small group sessions consisting of six people, who were in the general meeting to be in-depth interview sessions. In this small group, we focused on the patterns or themes that have emerged and were discussed in depth.

\section{Fieldwork results}

As Nellmapius is similar to many other townships in South Africa, so my observations about and engagement with this community, could assist me to understand the conditions in other townships because they are likely to have similar challenges.

\section{Identity is important}

The researcher heard the frustration expressed by the people of Nellmapius, especially those who are trying to earn a living. They have lost self-confident, self-worth, etc. They describe themselves as failures. They are people always expecting one to donate to them. There is a sense of undermining their abilities as human beings. There is a loss of human identity.

Because of the condition people in Nellmapius are living under, it crushed their thinking capacity and they end up thinking that life is not worth living and they cannot achieve anything in life (Manyaka 2010:103). Poverty kills identity, without which no one can rise and be a top achiever in the game of life. With healthy identity, there will be no mountain that can stand before such an individual. 


\section{Starting from nothing}

The researcher did participant observational research in Nellmapius starting a business from nothing, for example, ECD centres. Most of the women owning and running the centres started their education business because they were not working and were eager to put food on their tables.

Most started by selecting a name for the business, frequently the name of one of their children. They began to advertise through word-of-mouth and to write up cheap posters to inform the community about the centre. The advantage of this business is that parents or caregivers pay in advance. Once two or three parents have paid, the owner rushes to the local spaza shop to buy a small amount of groceries to feed the children, and her family.

These emerging entrepreneurs were in a position of 'nothingness' because they had no business plan or educational vision for the children. There was no legality in what they were doing and no proper training for the work. What moved them were their poverty and the need for a survival strategy.

The houses or sites where they operate their businesses are not zoned for an educational business. It requires lots of money to rezone a property, which these women do not have. Thus, it is not easy to move from illegality into legality and probably means that they will run their business illegally for the foreseeable future.

These women also lack business skills to operate their businesses professionally. This makes it impossible to get funding from the government and private sector. Without substantial training and support, it means there will be no improvement in how these women run their businesses.

As the managing director of Phenyo Christian College, the author has attended meetings for ECDs organised by the Gauteng Department of Health. One meeting was about applying for government funding; officials were there to distribute funding application forms and to help the ECD owners to complete them. Unfortunately, none of the women qualified for funding because of a lack of management of their businesses: they did not have proper paper work, receipts or records. An official chatting to the author remarked how very sad it was that people who desperately need funding do not qualify, but people from middle-income suburbs who have better resources do get funding because they have better management systems in place.

\section{Mushrooming of spaza shops in Nellmapius}

The author arrived in Nellmapius in 1996. At that time there was only one spaza shop in the area. Over time, spaza shops started mushrooming in Nellmapius. The men and women opening these businesses also started from nothing. The fact that they worked full-time, resulting in a monthly salary, set them apart from the ECD owners. However, they had the same problems as the ECD owners, namely that they did not have a business plan, financial management experience and the general skills needed to run a business. They did not register their businesses and they did not pay tax. All these early entrepreneurs failed to continue with their businesses, and by 2010, all spaza shops have been rented to foreign nationals.

\section{Lack of partnering or networking}

The researcher has also observed that people in the township do not partner with others; they prefer to do business alone. In our focused group, it has been found that this has contributed to people failing in business. If people partner or network, they can pool their financial resources to buy stock, which would reduce the financial services and transport costs; they could either pass these cost savings on to their local consumers or enjoy a higher return on their investment.

Today locals complain that foreign nationals have taken their businesses. From what the author has observed, the foreign nationals have money and business skills and they network. They combine their money when they go to stock up their stores. This has kept their prices low. The author has observed a symbiotic practice between property owners and spaza shopkeepers: The shopkeeper upgrades (builds on or renovates) the property using his or her own cash resources. The cost of the upgrade is offset against the cost of monthly rental of the site, or a share in the profits, until such time as the upgrade cost has been covered. Then the shopkeeper will start paying rent at an agreed rate.

\section{Non-profit organisations and co-operatives}

Over 12 months, the researcher has observed that many organisations and co-operatives have closed down. The focused group found that the major reason for this is that the people initiating these organisations lacked the skills to run them. Usually, funding was also a problem because every improvement in a business or organisation needs funding. Similar to the ECD owners, they were caught in the paradox of needing funding to improve their management skills, but without management skills, they were unable to qualify for funding.

\section{Failure of small businesses}

The author observed that many small-business operators, such as motor mechanics, car wash owners, those in the taxi industry, hairdressing and the catering industry through baking and cooking, etc., need good quality management systems.

Overall, the researcher's repeated participant observation was that the biggest problem in Nellmapius Township was that people lacked the confidence, business skills and money to be social and business entrepreneurs, but not the ability to identify a lack, see an opportunity to meet a need and the willingness to tackle the problem. 


\section{Church as a vehicle for the social entrepreneurship}

In Nellmapius, there are about 100 churches operating from different traditions. In the process of participant observation, it was clear that the church has no clear vision on how can they involve themselves in poverty eradication and empower the community members. What made this worse is that most of the pastors are not being theologically trained and lack ministerial training. The church will experience the same problem like other organisations.

The church as the main organisation in Nellmapius can play a role in preaching hope and self-reliance to their members. The church can empower the members to think well about themselves as people. Pastors and church leaders are the first on list to look for theological and leadership training.

In our focus group, it has been emphasised that church leaders can bring together members from different fields to discuss and find out how they can work together for betterment of their community. The focus group agreed that for the church to be transformational, it cannot only be operational on Sundays but should be operating seven days per week.

\section{What is practical theology?}

The author of this article defines spirituality as one's personal relationship with Jesus or the deity or divine. It can be encountered any time, any day or anywhere. Spirituality is not just about attending a service. It is the experience of God in everything that one does, enabling the transcendence from human experience to the experience of the Spirit of God. However, practical theology is a way of living and doing, which is informed by praxis. In practical theology, we are not consumed by systematic theology or historical theology; we are interested in the now, in what people are experiencing.

Ballard (1992) described the work of practical theology in this way:

The special task of practical theology is to start with the concrete, historical, immediate reality, critically evaluating and enabling the practical life of the church in all its forms, drawing on the findings of fundamental, historical, and systematic theology. (p. 29)

Browning (1996:15) adds 'Doing theology in close connection with the description of situations gets to the heart of what makes theology practical'.

Ganzevoort and Roeland (2014) suggest that practical theology is the theological study of lived religion, where 'religion' is defined as transcending patterns of action and meaning, emerging from and contributing to the relation with the sacred. The concepts of praxis and lived religion focus on what people do rather than on 'official' religion, its sacred sources, its institutions or its doctrines. Irrespective of whether practical theology is elaborated in terms of pastoral, empirical or public theology, the practical theologian is almost by necessity a concerned or engaged scholar (Ganzevoort \& Roeland 2014:91-101).

'Human nature is practical in thinking' (Browning 1996:8). In doing practical theology, we move from practice to theory and back to practice in a process described as 'practice-theorypractice' (Browning 1996:8-9; Manyaka 2014:3; 2015:5).

\section{Models of doing practical theology}

There are many models of doing practical theology. The author focuses on some of these.

Browning (1996:7) proposed a hermeneutical model that goes from practice to theory and back to practice. This is a practical theological process: It looks into the concrete context in order to understand it fully so that it can come to broadening the understanding of the context. After we have understood the context, we take a look into historical theology or the tradition of our texts through to systematic theology. This whole process will lead us into strategic practical theology, where to begin and how to respond to the current concern.

Osmer (2006:328-330) proposed four interrelated forms of research: descriptive-empirical, interpretive, normative and pragmatic. This model first likes to investigate in order to understand what is happening in a concrete context. Then the practical theologian will try to interpret what is happening, he or she will look into normative texts such as the scriptures and Christian traditions and lastly he or she will to try to formulate a programme of action that can lead to social or community transformation.

The post-foundationalist practical theology approach forces us to listen to people's stories of their struggles within reallife situations. Therefore, the post-foundationalist practical theologian is one who pays much attention to the stories of people who face real problems in their specific local context (Manyaka 2014:4; 2015:6; Muller 2011:204).

The people of Nellmapius are struggling with poverty and community transformation. These are the pastoral concerns upon which our reflection must be based (Manyaka 2015).

For researcher as a post-foundationalist practical theologian, the author believes his task is to listen to the stories of poverty and transformation and reflect on how to minimise poverty and realise or maximise true transformation. This article proposes that social entrepreneurship has the possibility to transform the township economy as a means of reducing poverty.

\section{Interdisciplinary conversations in practical theology}

The interdisciplinary conversation is essential in practical theology. It means that practical theologians will never again work in isolation from other disciplines, traditions or paradigms. 
Muller (2005:77) describes this way of thinking as 'always concrete, local and contextual, but at the same time [it] reaches beyond local contexts to transdisciplinary concerns' and 'a way of providing a responsible and workable interface between disciplines' (Muller 2011:3). Post-foundationalist practical theology can go beyond the specific local context into interdisciplinary territory and requires good communication between different disciplines. Van Huyssteen (2006) writes:

A postfoundationalist approach helps realize ... that we are not the intellectual prisoners of our own context or traditions, but that we are epistemically empowered to cross contextual, cultural, and disciplinary borders to explore critically the theories, meanings, and beliefs with which we and others construct our world. (p. 21)

Van Huyssteen (2006:148; Muller 2011) uses the term 'wide reflective equilibrium' to point to the optimal, but fragile, communal understanding we are capable of in any given moment. A post-foundationalist notion of reality enables us to communicate across boundaries and move transversally from context to context, from one tradition to another, from one discipline to another. He continues that in this wide reflective equilibrium, we find the safe but fragile public space we have been searching for, a space for shuttling back and forth between deep personal convictions and the principles that result from interpersonal judgements.

Therefore, a post-foundationalist practical theologian will invite social workers, teachers, nurses, engineers and politicians who are members of the church to reflect on social entrepreneurship and how to empower the community to start their businesses or how to promote entrepreneurial activities in townships. In this process, community members are not merely spectators; they own the process, because they are ones who must carry the process forward.

\section{Starting a new venture or business}

Starting of business follows identification of an opportunity in the market or in the old equilibrium in the community that encourages the marginalisation of a particular group in society.

Kaplan and Warren (2007:4-5) explain that essentially the entrepreneurship process includes planning, organising, operating and assuming the risk of a business venture. They note that there are many approaches that could lead to success, but each requires identifying of opportunity, extending a vision by careful strategic planning, being capable of doing even the most miniscule task and having the will to persevere when times are rough. Regarding opportunity recognition and development, Kaplan and Warren (2007:36) list five phases that must be negotiated successfully by the entrepreneur:

1. Phase one: Seize the opportunity.

2. Phase two: Investigate the need through market research.

3. Phase three: Develop the plan.

4. Phase four: Determine the resources needed.

5. Phase five: Manage the business.

\section{Research findings}

People who live in townships need lots of motivation because of the horrible conditions they live in (Manyaka 2010:96). The motivational messages should stress the abilities and potentials that each person possesses. Many township dwellers have been crushed by poverty, and consequently, their self-esteem is very low. Therefore, township adults and youths must be encouraged to accept themselves and become proud of their identity, so that they do not perpetuate a generational cycle of emotional deprivation and disempowerment.

As well-known TV personality Pat Pillay said 'What Africa needs is an education system that builds strong identity, strong self-concept and a principle-centred champion mentality, to unlock the champion within' (Sunday Independent 2011).

Empowerment should build and strengthen the inner person, by restoring the human identity of those individuals. Identity refers to the way we feel about ourselves (Josselson 1987:13; Manyaka 2010:6). The restored human identity is formed when those individuals begin to feel good and have higher levels of self-confidence, self-knowledge, self-love and selfesteem. It is known as the 'power within' (Kim et al. 2007:28). As Lee (2001:51) notes, there are three levels of empowerment: Personal, interpersonal and political.

People who cannot accept themselves cannot interact well with others (Manyaka 2010:5). Working in Nellmapius, the author has observed that Africans living there do not believe in themselves and in one another. They prefer other tribes to their own township residents. They are suspicious of others - one hears them saying to those who would like to start a business 'You want to get rich with my money'. The author has observed how they will stop supporting local business owners and spread negative massages about locals. And they are reluctant to form partnerships to enhance their businesses. As previously noted, the author has observed that many cooperatives failed because township residents do not trust one another. Yet foreign nationals seem to be prospering in their township businesses, partly because of their business skills and because they work together. If South Africans in the township chose to partner, they would attract business funding from government and the private sector, which would assist in developing the township economy.

Once intra- and inter-personal relationships are addressed (as a module in the business training curriculum) training in how to start and run a business can commence. Ideally, entrepreneurial activities should start in the home and continue through school to university level.

The restored human identity would be followed by releasing human potential and higher productivity. Kim et al. (2007:28) call it the 'power to': Power to create new opportunities without domination and power to make independent decisions that determine and demonstrate such agency. 
Such people, with the power to create the new opportunities, are social and business entrepreneurs. These are the people who must receive adequate entrepreneurial education so that they can play an important role in transforming the township economy.

The third element of power is 'power with' (Kim et al. 2007:28). This covers the communal dimensions, such as group solidarity or collective actions, which acknowledge that a positive change may often be effected through acting together, rather than alone.

In this 'power with' township, government and the private sector must work together to develop the township economy. Indeed, it will take concerted, coordinated and committed action by all stakeholders working collaboratively for township economies to develop. Government policy and legislation must result in favourable regulations for small businesses, in the township and elsewhere, so that they can play a significant role in the process of economic development. Government and the private sector should improve the quality of entrepreneurial training. The private sector can partner with or mentor small-business owners in the townships so that the small-business owners can learn from them. By so doing, the township economy would be improved greatly.

Entrepreneurship must start with human empowerment; that is, addressing issues of identity, self-worth intra- and interpersonal relationships. These must be coupled with business skills to make a successful entrepreneur. Therefore, the author proposes the following model of entrepreneurship: Identity $\rightarrow$ interpersonal $\rightarrow$ business skills. Given the author's experience and observations in Nellmapius, the author believes that unless entrepreneurial training starts with development of personal identity and includes modules on intra- and interpersonal relationships, business skills training alone will not be effective in creating the socially minded entrepreneurs needed to develop the township economy.

\section{Conclusion}

According to this article, social entrepreneurs have an important role to play in social transformation. As regards non-profit organisations that the researcher has mentioned in the previous sections, the only way to be sustainable is when they become entrepreneurial and are able to create profit in their daily operations. And this profit is not to be pocketed, but it should be used to achieve their social goals.

With this state of high unemployment mentioned on in the Introduction, social entrepreneurship can be a solution. Social entrepreneurs will continue adding value to the society despite economic meltdown.

\section{Acknowledgements Competing interests}

The author declares that he has no financial or personal relationships which may have inappropriately influenced him in writing this article.

\section{References}

Angrosino, M., 2007, Doing ethnographic and observational research, Sage, USA

Ardichvili, A., Cardozo, R. \& Ray, S., 2003, 'The theory of entrepreneurial opportunity identification and development', Journal of Business Venturing 18(1), 105-123.

Austin, J., Stevenson, H. \& Wei-Skillern, J., 2006, 'Social and commercial entrepreneurship: Same, different or both?', Entrepreneurship Theory and Practice 30(1), 1-22. https://doi.org/10.1111/j.1540-6520.2006.00107.x

Ballard, P., 1992, 'Can theology be practical?', in D. Willows \& J. Swinton (eds.), Spiritual dimension of pastoral care: Practical theology in a multidisciplinary context, pp. 27-35, Jessica Kingsley Publishers, Philadelphia, PA.

Browning, D.S., 1996, A foundational practical theology: Descriptive and strategic proposal, Fortress Press Book, Minneapolis, MN.

Cole, A.H., 1949, 'Entrepreneurship and entrepreneurial history', in Research Center in Entrepreneurship History (ed.), Change and the entrepreneur, pp. 85-107, Harvard University Press, Cambridge, MA.

Couch, W.T., 1963, Collier's encyclopaedia, vol. 8, The Crowell-Collier Publishing Company, Springfield, $\mathrm{OH}$.

Dees, J.G., 1998, The meaning of 'social entrepreneurship', Stanford University: Draft Report for the Kauffman Center for Entrepreneurial Leadership, viewed 31 October 2013, from http://community-wealth.org/sites/clone.community-wealth.org/files/ downloads/paper-dees.pdf

Drucker, P.F., 1964, Managing for results, Harper and Row Publishers, New York.

Emery, H.G., 1956, The new century dictionary of the English language, Revision editor, Catherine B., Avery, New York.

Frith, A., 2011, Sub place, viewed 28 December 2016, from Census2011AdrianFrith. com

Ganzevoort, R.R. \& Roeland, J., 2014, 'Lived religion: The praxis of practical theology', International Journal of Practical Theology 18(1), 91-101.

Herbert, R.F. \& Link, A.N., 2006, Historical perspectives on the Entrepreneur, Foundations and Trends, vol. 2(4), Now Publishers Inc., Boston, MA.

Herrington, M. \& Kew, P., 2016, South African Report 2015/2016. Is South Africa heading for an economic meltdown? Global Enterprise Monitor, viewed 21 June 2016, from http://www.gemconsortium.org/report/49537

Herrington, M., Kew, J. \& Kew, A., 2009, Tracking entrepreneurship in South Africa: A GEM perspective. Global Entrepreneurship Monitor, South African Report, viewed 24 June 2014, from http://www.gemconsortium.org/docs/ viewed 24 download/604

Josselson, R., 1987, Pathways to identity development in women, Jossey-Bass Publishers, San Francisco, CA.

Kaplan, J.M. \& Warren, A.C., 2007, Patterns of entrepreneurship management, 6th edn., Wiley, Hoboken, NJ.

Kim, J.C., Watts, C.H., Hargreaves, J.R., Ndlovu, L.X., Phetla, G. \& Morison, L.A., 2007 'Understanding the impact of a microfinance intervention on women's empowerment and reduction of intimate partner violence in South Africa', American Journal of Public Health 97(10), 1794-1802.

Lee, J.B.A., 2001, The empowerment approach to social work practice: Building the beloved community, 2nd edn., Columbia University Press, New York.

Makhura, D., 2015, Gauteng State of the Province address, 23 Feb. 2015, viewed 14 May 2015, from http://www.gautengonline.gov.za/Documents/SOPA $\% 20$ 2015\%20Speech\%20booklet.pdf

Manyaka, S.J., 2010, 'The marginalized stories of people who live in poverty: A pastoral narrative approach to community transformational development', Unpublished PhD thesis, University of Pretoria, Pretoria.

Manyaka, S.J., 2014, 'Towards restoration of human identity: Practical theology exploring possibilities of re-imagining the discourse of reconciliation and social cohesion in SA', HTS Teologiese Studies/Theological Studies 70(1), Art. \#2624, 1-5. https://doi.org/10.4102/hts.v70i1.2624

Manyaka, S.J., 2015, 'Social entrepreneurship: A solution for transforming the disadvantaged community of Nellmapius', HTS Teologiese Studies/Theological Studies 71(3), 7. https://doi.org/10.4102/hts.v71i3.2821

Martin, R.L. \& Osberg, S., 2007, 'Social entrepreneurship: The case study for definition', Stanford Social Innovation Review, viewed 31 October 2013, from http://www.ssireview.org/articles/entry/social_entrepreneurship_the_case_ for_definition

Mitton, D.G., 1989, 'The complete entrepreneur', Entrepreneurship Theory and Practice 13(3), 9-20.

Muller, J.C., 2005, 'A postfoundationalist, HIV-positive practical theology', Practical Theology in South Africa 20(2), 72-88.

Muller, J.C., 2011, 'Postfoundational practical theology for a time of transition', HTS Teologies Studies/Theological Studies 67(1), Art. 837, 1-5.

O'Reilly, K., 2009, 'Participant observation', in Key concepts in ethnography, Sage key concepts, pp. 150-157, Sage, London.

Osmer, R.R., 2006, 'Towards a transversal model of interdisciplinary thinking in practical theology', in F.L. Shults (ed.), The evolution of rationality: Interdisciplinary essays in Honor of J. Wentzel van Huyssteen, pp. 327-3345, Eerdmans, Grand Rapids, MI.

Pesciarelli, E., 1989, 'Smith, Bentham, and the development of contrasting ideas on entrepreneurship', History of Political Economy 21(3), 521-536. https://doi. org/10.1215/00182702-21-3-521 
Pieterse, H.J.C., 2001, Preaching in the context of poverty, University of South Africa, Pretoria.

Ramokgopa, K., 2015, State of the capital address: 14 May 2015, viewed 21 June 2016 , from http://www.tshwane.gov.za/Documents/SOCA 2015_EM autoqueue final version.pdf

Schumpeter, J.A., 1934, Theory of economic development, 2nd edn., Harvard University Press, Cambridge, MA.

Skrutkowaski, M., 2014, 'Doing research in your own organisation: Being native, going stranger', in Critical management research: Reflection from the field, pp. 101-118, Sage, London. https://doi.org/10.4135/9781446288610

Sobel, R.S., 2008, Entrepreneurship. The concise encyclopaedia of economics, viewed 21 June 2016, from http://www.econlib.org/library/Enc/Entrepreneurship.htm
Statistics South Africa (Stats SA), 2016, Quarterly Labour Force Survey (QLFS), 1st Quarter 2016, viewed 20 June 2016, from http://www.statssa.gov.za/publications/ P0211/P02111stQuarter2016.pdf

Sunday Independent, 2011, 'Life Champion newsreader Pat Pillay eyes MBA in social enterprise', Sunday Independent, 30 October, p. 19

Taborda, J., 2016, South Africa unemployment rate, viewed 09 January 2107, from www.tradingeconomics.com

Turnbull, J., 2004, Oxford advanced learner's dictionary, 7th edn., Oxford University Press, USA.

Van Huyssteen, W., 2006, Alone in the world? Human uniqueness in science and theology, William B. Eerdmans Publishers, Grand Rapids, MI. 